Krzysztof Knop ${ }^{l}$, Krzysztof Mielczarek ${ }^{2}$,

\title{
ASPEKTY DOSKONALENIA PROCESU PRODUKCYJNEGO
}

\begin{abstract}
Streszczenie: W rozdziale dokonano analizy podejścia do doskonalenia w organizacji, ze zwróceniem uwagi na doskonalenie procesów w firmach produkcyjnych. Przedstawiono definicję doskonałości i doskonalenia wg różnych autorów, podkreślono nierozerwalny związek tego pojęcia z jakością. Zaprezentowano różne aspekty i podejścia do doskonalenia procesu produkcyjnego, opisano na co należy zwracać uwagę podejmując się takich działań, określono co może być obiektem czy też obszarem doskonalenia, jak należy skutecznie prowadzić proces doskonalenia, jakie są wymagania dla takiego procesu, jakie metody, techniki i narzędzia można w tym celu użyć. Odniesiono skuteczność podstawowych koncepcji doskonalenia produkcji i jakości ze względu na spełnienie wymagań typu dobrze, szybko i tanio.
\end{abstract}

Słowa kluczowe: doskonałość, doskonalenie, proces produkcyjny

\section{Doskonałość a doskonalenie}

„wczorajsze duże osiągnięcie musi stać się dzisiejszym minimum, a wczorajsza doskonałość staje się dzisiejszą codziennością"

P. Drucker, guru zarządzania na świecie

„jakość to pewien stopień doskonałości”"

Platon, grecki filozof

„jakość to wszystko to co można poprawić"

M. Imai, Kaizen Institute

\footnotetext{
1 Mgr inż., Politechnika Częstochowska, Wydział Zarządzania, Instytut Inżynierii Produkcji, e-mail: kknop@poczta.fm

2 Mgr inż., Politechnika Częstochowska, Wydział Zarządzania, Instytut Inżynierii Produkcji, e-mail: mielczarek@zim.pcz.pl
} 
Doskonałość jest to termin określający cechę m.in. osoby, czynności, umiejętności, dzieła, przedmiotu, produktu (TATARKIEWICZ W. 1976). Słowo doskonałość jest spolszczoną wersją łacińskiego perfectio, zaś doskonaty - perfectus. Perfectio oznaczało dokonanie czegoś, zrobienie do końca. Doskonałość w swym dosłownym znaczeniu określa dokonanie, wykończenie (dokonany, wykończony). Samuel Linde dowodzi, że polskie słowo "doskonały" pochodzi od "dokonały", a tylko wejście litery $s$ w środek przesłoniło jego pochodzenie ${ }^{3}$.

W myśli greckiej doskonałe jest to, co istniało zawsze - wieczne idee (Platon). Arystoteles w Metafizyce pisał, iż doskonate jest to, co jest zupetne, zawiera wszystkie należne części, a także to, co osiagnęło swój cel. Określano również, iż to co spełnia wszystkie funkcje, do których zostało stworzone, również zasługuje na miano doskonałego. Innymi cechami miały być także: harmonijność, budowa według jednej, właściwej zasady, zgodność, prostota (niezłożoność) (św. AMBROŻY: De Isaac et anima, VII).

Termin doskonatość ma wiele synonimów tj.: wyborność, świetność, wybitność, bezblędność, brak możliwości bycia jeszcze lepszym, szczyt, zupetność, brak jakiejkolwiek wady, niedostatku lub możliwości ulepszenia 4 .

Wg słownika PWN doskonaty to: 1. Odznaczający się najwyższa jakościa, majacy wszelkie zalety. 2. Zupetny, absolutny. „Doskonały” różni się od słowa „najlepszy”. Można być najlepszym w swoim rodzaju, doskonałość jest zaś absolutna. Bywa ona rozumiana jako ideał, pojęcie graniczne, konstrukcja idealna, ale nieosiągalna.

Wg Uniwersalnego słownika języka polskiego doskonały oznacza „wolny od jakichkolwiek blędów, usterek, wad; najlepszy, wzorowy, niezrównany". Ta definicja zakłada, że coś albo jest doskonałe, albo nie. Słowo to jest objaśniane za pomocą synonimów typu największy lub najwyższy, czyli coś, co wyraża maksymalny stopień natężenia jakiejś cechy. Wbrew pozorom, jak wyjaśnia Mirosław Bańka z PWN,

\footnotetext{
${ }^{3}$ http://print-partner.com.pl/print_pub/publik/2015/doskonalosc-to-osiagniecie-celu.html

${ }^{4}$ https://pl.glosbe.com/pl/pl/doskona\%C5\%82o\%C5\%9B\%C4\%87
} 
przymiotnik dokonały podlega stopniowaniu. Bańka wskazuje, że słowu doskonały należy przypisać dwa znaczenia: w jednym, jako określenie czegoś o maksymalnym natężeniu - słowo to nie podlega wtedy stopniowaniu (np. próżnia doskonała), w drugim zaś funkcjonuje jako synonim słowa wyśmienity lub znakomity i jest stopniowalne ${ }^{5}$.

Doskonałość to także to, co spetnia wszystkie wtaściwe sobie funkcje oraz to, co osiagnęto swój cel, coś, co jest proste, jednolite, nieztożone (TATARKIEWICZ W. 1976) Oznacza to, że nie ma doskonałości bezwzględnej - cele mogą być różne, a doskonałość zmienia się w czasie, bo zmieniają się cele. Autor podkreśla, że należy myśleć i dążyć do doskonałości, do doskonałości w danych warunkach, w danym czasie, przy danych wymaganiach klienta. Należy tylko zdefiniować sobie swój cel doskonałości.

Termin doskonatość wiązano z jakościa. Pierwsze pisane definicje jakości, porównywały ją z doskonałościa, a działo się to w starożytnej Grecji. Platon zdefiniował ,jakość jako pewien stopień doskonatości”. Stagiryta określił że ,jakość to doskonałośc”", Lao Tse podkreślił także że „jakość to doskonatość, perfekcja wykonania” (HORBACZEWSKI D. 2006). Oznacza to, że pojęcia „doskonałość” i ,jakość” będą zawsze pozostawać we wzajemnym związku (SZCZEPAŃSKA K. 2011), przy czym jakość to raczej droga do tego, by się do tej doskonałości zbliżyć (WIŚNIEWSKA M., MUZOLF A. 2012).

Pojęcie doskonalenia jest często rozumiane jako synonim pojęć: ulepszanie, usprawnianie, unowocześnienie, zmiana, modernizacja, itp.

Doskonalenie odnosi się do wszystkich obszarów życia człowieka i organizacji. Dążenie do doskonałości jest udziałem wielu organizacji i osób, wynika to z podstawowej zasady, że ,jeśli się nie rozwijasz tak naprawdę się cofasz".

Doskonalenie jest procesem, który nigdy się nie kończy, ponieważ bliższe i dalsze otoczenie ulega ciągłym zmianom. Zmusza to firmy do działania i stawiania sobie wymagań. Czym się odznacza firma „,doskonała”? Firma doskonała definiowana jest jako taka, która żyje

\footnotetext{
${ }^{5}$ http://sjp.pwn.pl/slowniki/doskona\%C5\%82y.html
} 
swoim zaangażowaniem wobec ludzi i wierzy $w$ skuteczność swojego działania. Cechuje je też szybkie dziatanie, troska o jakość ustug, wdrażanie praktycznych innowacji, a także świadomość, że do osiagnięcia sukcesu konieczne jest zaangażowanie wszystkich pracowników (SKRZYPEK E. 2010).

\section{Podejścia do doskonalenia procesu produkcyjnego}

Każda firma powinna nieustannie udoskonalać swoje procesy. Ten pęd w kierunku doskonalenia swoich procesów jest udziałem także firm produkcyjnych. Powstają nowe stanowiska pracy w takich firmach określane jako specjalista ds. ciagłego doskonalenia, specjalista ds. optymalizacji procesu produkcji, specjalista ds. kaizen, czy inne podobne, które mają zapewnić, że takie działania będą realizowane i jednocześnie podkreślić zaangażowanie firmy, jej najwyższego kierownictwa ( $\mathrm{w}$ oczach klientów i pracowników firmy) w proces podążania „ku lepszemu”. Stanowiska takie, już ze swojej nazwy, są dużym wyzwaniem dla pracowników aplikujących lub już pracujących w takim charakterze, bo jak wiadomo doskonalenie jako proces nigdy się nie kończy... osoba taka zawsze ma „ręce pełne roboty”, musi bowiem wykazywać się dużym inwencją i kreatywnością w identyfikacji i definiowaniu obszarów doskonalenia a następnie w realizacji takich działań, bo oczywiście z efektów takiej pracy jest rozliczana przez swojego przełożonego.

Warto podkreślić, że doskonalić w firmie nie można (i nie da się) od razu wszystkiego, nie będzie to działanie skuteczne ani efektywne. Działania doskonalące powinny skupiać się przede wszystkim na procesach strategicznych (a także subprocesach w ramach tych procesów) dla danej działalności, które tworzą istotną wartość dodaną dla klienta oraz które, w efekcie mogą zwiększyć przewagę konkurencyjną przedsiębiorstwa. Badania dowodzą, że programy doskonalenia procesów, które nie odwołują się bezpośrednio do zwiększenia przewagi konkurencyjnej, skazane są na porażkę. Takie podejście może prowadzić 
do nieoptymalnego wprowadzania usprawnień i zaniedbywania działań, które wymagają największej uwagi ${ }^{6}$.

$W$ zależności od pionu organizacji potrzeba udoskonalania procesów zwykle wyglada inaczej. W niektórych działach w firmie (produkcji, finansach, operacyjnym) działania doskonalące raczej powinny przebiegać łatwiej, ze względu na to, że w tych działach kładzie się nacisk na zapewnienie takich celów jak spójność, rzetelność i efektywność. Pracownicy takich działów nie powinny mieć problemu ze zmierzeniem się z procesem doskonalenia. $Z$ kolei osoby zatrudnione $n p$. w działach sprzedaży i marketingu, które koncentrują się na relacjach i innowacyjności, mogą już mieć w tym względzie pewne trudności.

Ważna jest wiedza i doświadczenie osoby (lub grupy osób) podejmującej się próby udoskonalenia procesu. To od niej zależeć będzie (od wiedzy, doświadczenia, determinacji, zaangażowania takiej osoby), czy działania te przyniosą zamierzony skutek, czyli czy to, co sobie taka osoba zaplanuje zostanie zrealizowano. Oczywiście należy zapewnić jej niezbędne środki (finansowe, rzeczowe, informacyjne) do realizacji takiego celu. Osoba odpowiedzialna za udoskonalenie procesu, która nie wie w jaki sposób ma się do tego zabrać, nie ma właściwej motywacji, nie jest do tego przygotowana, ma ograniczona wiedzę na temat sposobów (metod, narzędzi, technik) doskonalenia, naraża zarówno firmę, jak i swoją karierę na niebezpieczeństwo.

Firmy produkcyjne mogą orientować procesy doskonalenia na każdy aspekt swojej działalności. Doskonalić można w takiej firmie wszystko np. zarzadzanie, jakość, produkcję, wyroby, procesy, prace, itd.

Przedmiotem doskonalenia procesu produkcyjnego może być caty proces produkcyjny jak i poszczególne subprocesy tego procesu (proces wytwórczy, proces badań i rozwoju czy proces dystrybucji $i$ obstugi klienta) czy operacje, czynności a nawet ruchy robocze wykonywane w ramach tych procesów.

${ }^{6}$ http://www.hbrp.pl/news.php?id=423\&PHPSESSID=d8d49ef253d7ecf3474c6ed7c89e23 62 
Doskonalenie procesu produkcyjnego może być zorientowane na samych procesach lub wynikach, rezultatach tych procesów tj. np. wyrobach, usługach.

Doskonalenie procesu produkcyjnego może przybierać formę czynna (realizowane może być $\mathrm{w}$ trakcie trwania procesu) lub bierna (po zrealizowaniu procesu).

Doskonalenie procesów może przybierać formę dziatań proaktywnych (wyprzedzających) lub reaktywnych (w wyniku np. reklamacji nadesłanych przez klientów).

Doskonalenie procesu produkcyjnego może dotyczyć jakości tego procesu, czasu trwania oraz kosztów.

Doskonalenie procesów produkcyjnych przynosi wymierne efekty, nie tylko ekonomiczne (finansowe). Jego efektem może być redukcja $i$ optymalizacja kosztów, poprawa jakości pracy, wzrost wydajności i produktywności, usprawnienie komunikacji oraz poprawa efektywności i skuteczności działania.

Doskonalenie procesów produkcyjnych to zadanie wymagajace systematycznego, planowego $i$ bazowanego na faktach podejścia do tematu (HUBER Z. 2006). Znajomość procesu który chcę się monitorować i doskonalić to pierwszy $i$ podstawy element $w$ drodze do udoskonalenia procesu. Należy w pierwszej kolejności dobrze poznać proces, najlepiej go także narysować. W tym celu można wykorzystać takie narzędzia graficzne jak mapa przepływu, schemat blokowy, ujęcie technologiczne. Następnym etapem jest zebranie danych $i$ ich analiza. Analiza danych może być wykorzystywana do doskonalenia procesu w różny sposób. Można za jej pomocą wykrywać zakłócenia w procesie, znajdować przyczyny wpływające na problemy z jakością, dobierać optymalne ustawienia dla procesu, porównywać różne procedury wytwarzania i wiele innych. W tym celu można wykorzystać różnego rodzaju narzędzia analizy danych (także informatyczne). Wymagane jest, aby 
stosowane narzędzie analizy danych umożliwiało współpracę wielu osób, zapewniało kontrolę dostępu, łatwe korzystanie z danych i wyników ${ }^{7}$.

W celu doskonalenia procesu produkcyjnego można wykorzystać różne podejścia bazujące na:

- wykrywaniu przyczyn, poprzez wskazanie które zdarzenia, zmiany ustawień, właściwości surowców itp. wpływają na jakość wyrobu,

- przewidywaniu wyniku procesu przed jego zakończeniem przewidywanie, jakie będą cechy produktu po zakończeniu procesu, co umożliwia dobranie parametrów dalszej części procesu, tak aby skorygować ewentualne, niepożądane wartości,

- doboru najlepszych parametrów procesu - przewidywanie, jaki będzie wynik procesu, przy danych ustawieniach,

- wczesnym wykrywaniu problemów zjakościq - wskazanie na podstawie cech surowców, przebiegu procesu i wyników szybko dostępnych badań, czy produkt jest dobry czy zły, a w konsekwencji, czy należy wprowadzać korekty do procesu,

- wykrywaniu zmian wprocesie - monitorowanie odchyleń rzeczywistych właściwości procesu od tych, które wynikają z założeń. Jeśli odchylenia gwałtownie wzrosną jest to sygnał, że coś się stało $\mathrm{z}$ procesem nie tak.

Następnie zostaje, na podstawie przeprowadzonej analizy danych, określenie i wprowadzenie działań korygujacych i zapobiegawczych. Wprowadzenie działań korygujących i zapobiegawczych uważa się za kwintesencje procesów doskonalenia w przedsiębiorstwach mających wdrożony system zarządzania wg normy ISO 9001. Norma ISO 9001 (a także normy pochodne - ISO 14001, PN-N-18001, ISO 27001 i inne) wskazują, że podstawowymi działaniami doskonalącymi są właśnie dziatania korygujace oraz zapobiegawcze. Natomiast norma ISO 9004 wprowadza dodatkowe pojęcia - zapobieganie stratom (rozszerzenie działań zapobiegawczych) oraz ciagłe doskonalenie organizacji.

\footnotetext{
${ }^{7}$ http://www.statsoft.pl/Rozwiazania/Zastosowania-technologiczne/Optymalizacjaprocesow
} 
Działania korygujące są przykładem działań reaktywnych, są podejmowane na skutek wykrycia niezgodności (błędu, awarii, incydentu, wypadku, itp.) (niezgodność powstała, następnie w odniesieniu do niej proponuje się działania korygujące). Na czym te działania polegają? Polegają na wprowadzeniu zmian, które pozwolą uniemożliwić powtórne wystąpienie niezgodności. W tym celu bada się jakie były przyczyny wystąpienia niezgodności. Od tej analizy zależy skuteczność całego procesu. Następnie określa się, w jaki sposób można usunąć przyczyny. Kolejnym krokiem jest zaplanowanie i wykonanie działań, które zlikwidują przyczyny wystąpienia niezgodności lub przynajmniej je znacząco ograniczą. Wprowadzenie działań korygujących musi zostać zweryfikowane - należy więc sprawdzić, czy w wyniku wprowadzonych zmian rzeczywiście niezgodność nie może się powtórzyć. ${ }^{8}$.

Działania zapobiegawcze są przykładem działań doskonalących proaktywnych (podejmowane są przed wystąpieniem niezgodności w celu zapobieżenia lub ograniczenia możliwości jej wystąpienia). Punktem wyjścia dla działań zapobiegawczych jest stwierdzenie możliwości wystąpienia niezgodności (jednak niezgodność ta jeszcze nie wystąpiła). Mówimy w tej sytuacji o potencjalnej niezgodności. Zadaniem działań zapobiegawczych jest usuwanie przyczyn potencjalnych niezgodności. Dzięki temu organizacja nie musi ponosić kosztów usuwania niezgodności ${ }^{9}$.

Po wykonaniu takiego cyklu działań doskonalenie procesu można uznać za zakończone. Przy czym należy mieć na względzie to, że doskonalenie jako proces nigdy się nie kończy, wykonanie doskonalenia oznacza osiągnięcie pewnego optimum/standardu - który to z kolei może stanowić punkt wyjścia do podjęcia działań w kolejnym procesie doskonalenia.

Celem podejmowanych działań doskonalących proces produkcyjny jest osiągnięcie wymiernych efektów ekonomicznych i produkcyjnych.

\footnotetext{
${ }^{8} \mathrm{http}: / / \mathrm{mfiles} . \mathrm{pl} / \mathrm{pl} / \mathrm{index} . \mathrm{php} / \mathrm{Dzia} \% \mathrm{C} 5 \% 82 \mathrm{ania} \_d o$ oskonal\%C4\%85ce

${ }^{9}$ Ibidem
} 
Do takich korzyści można zaliczyć: sprawność procesu produkcyjnego, terminowość wykonywania zadań, identyfikacja czynników wplywających na jakość produktów, skracanie czasów międzyoperacyjnych, minimalizacja zapasów. Istotną rolę zarówno $\mathrm{w}$ doskonaleniu dotychczasowych procesów produkcyjnych lub ich przeprojektowaniu odgrywają nowoczesne metody organizacji i zarządzania procesami produkcyjnymi wynikające z dążenia do poprawy wydajności i redukcji kosztów (STANIEWSKA E. 2015).

Procesy produkcyjne można także doskonalić stosując wiele metod, $n a r z e ̨ d z i$ i technik. Wybór danej metody musi być podyktowany wnikliwą analizą sytuacji problemowej, rodzajem i złożonością problemu oraz czasem realizacji. Przykładowe techniki jakie można wykorzystać w tym celu to: $5 x$ dlaczego, $5 W 1 H, 5 G$, diagram Ishikawy/4M/5MQS, karta OPL, analiza FMEA, Poka-Yoke, DoE, SPC.

Istnieje wiele koncepcji, filozofii, programów doskonalenia (nie tylko) procesów produkcyjnych, wśród najważniejszych należy wymienić:

- Lean manufacturing/Lean production,

- Six Sigma,

- Agile Manufacturing,

- TQM,

- Kaizen.

Część z nich to koncepcję które nie zajmują się wyłącznie doskonaleniem samego procesu produkcyjnego czy wytwórczego (np. Six Sigma, TQM, Kaizen), ale doskonalenia procesu produkcyjnego jest jednym z obszarów zainteresowania tych koncepcji. Najsilniej powiązane $\mathrm{z}$ doskonaleniem procesu wytwórczego są koncepcję typu Lean manufacturing/Lean production oraz Agile Manufacturing.

Zastosowanie koncepcji Lean Manufacturing w wielu przedsiębiorstwach i ich zakładach produkcyjnych przyczyniło się do poprawy produktywności, obniżenia kosztów, poprawy jakości produkcji i skrócenia czasów realizacji. Zastosowanie koncepcji Agile Manufacturing przyczynia się do szybszej reakcji na zróżnicowane wzorce popytu; lepszego zorientowania na klienta i rynek, lepszego 
zrozumienia potrzeb klienta i bliższych relacji z klientem, elastyczności produkcji $w$ różnych partiach produkcyjnych, elastyczności produkcji produktów unikatowych; elastyczności produkcji szerokiego zakresu produktów; zdolności do szybkiego reagowania na nowe szanse rynkowe oraz do tworzenia wirtualnych korporacji $i$ działania $w$ warunkach zmian, a także większa odporność na ryzyka ${ }^{10}$.

\section{3. „Diabelski” trójkąt a skuteczność metod i technik doskonalenia procesu produkcyjnego}

Jedna z zasad mówi, że nie można produkować spełniając wszystkie kryteria tanio, szybko $i$ dobrze. $\mathrm{Z}$ tej trójki tylko kombinacja dwóch potrzeb jest możliwa do zapewnienia w procesie produkcyjnym. Podkreśla to tzw. „diabelski trójkąt” (rys. 1), z uwagi na to, że można być na wszystkich bokach trójkątach na raz (nie można osiągnąć wszystkich wymagań na raz).

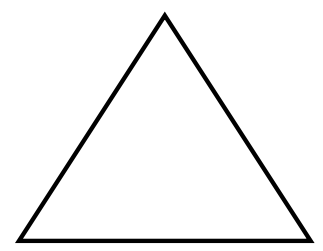

TANIO i SZYBKO? - nie będzie DOBRZE

DOBRZE i SZYBKO? - nie będzie TANIO

TANIO i DOBRZE? - nie będzie SZYBKO

TANIO, DOBRZE i SZYBKO - niestety

można wybrać tylko 2 spośród 3 wariantów!

Rys. 1. Idea „diabelskiego trójkąta”.

Źródto: Interpretacja wtasna

Tą zasadę można także odnieść do doskonalenia procesu produkcyjnego. Trudno jest, a wręcz nie możliwe jest żeby zastosować jakąś technikę, metodę, narządzie doskonalenia, które będzie działać na tyle kompleksowo że pozwoli nam udoskonalić proces ze względu na trzy kryteria tanio, szybko i dobrze. Idąc dalej, sam proces doskonalenia

${ }^{10} \mathrm{http}: / /$ www.log24.pl/artykuly/przedsiebiorstwo-agile, 1464 
nie może spełniać tych trzech kryteriów jednocześnie, w tym samym czasie.

Do najczęściej analizowanych możliwości doskonalenia procesu produkcyjnego zalicza się wykorzystanie efektu synergii poprzez:

- podniesienie jakości procesu/wyrobu przy jednoczesnym obniżeniu kosztów procesu/wyrobu (dobrze i tanio);

- podniesienie jakości procesu/wyrobu przy jednoczesnym skróceniu czasu realizacji procesu (dobrze i szybko);

- obniżenie poziomu kosztów procesu przy jednoczesnym skróceniu czasu realizacji procesu (tanio oraz szybko) (TROJANOWSKA J., KOLIŃSKI A. 2011).

Istnieją koncepcję zarządzania i doskonalenia produkcji i jakości, które pozwalają osiągnąc różne cele, bazując na koncepcji trójkąta. Zestawienie podstawowych koncepcji zarządzania i doskonalenia produkcją z podstawowymi wymaganiami typu dobrze, tanio i szybko przedstawia rys. 2 .

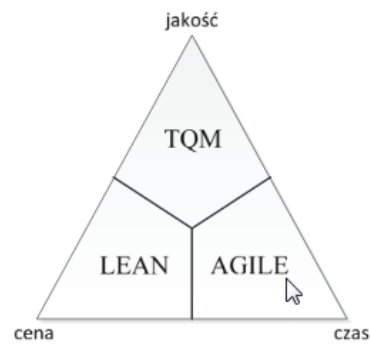

Rys. 6.2. „Diabelski trójkąt” a podstawowe koncepcje zarządzania i doskonalenia jakości i produkcji.

Źródlo: TROJANOWSKA J., KOLIŃSKI A. 2011

Dokonano krótkiej charakterystyki analizowanych koncepcji zarządzania i doskonalenia produkcją $\mathrm{z}$ punktu widzenia tego, jakich rezultatów można oczekiwać klienci (odbiorcy wyrobu) poprzez ich wdrożenie. Wyniki przedstawia tablica 1. 
Zeszyty Naukowe

$\operatorname{Nr} 1(2)$

Quality. Production. Improvement

Tablica 1. Podstawowe zalożenia strategiczne analizowanych koncepcji zarządzania i doskonalenia jakości i produkcji

\begin{tabular}{|c|c|}
\hline Koncepcja & Podstawowe zalożenia koncepcji \\
\hline \multirow{3}{*}{ Agile Manufacturing } & minimalizacja czasu \\
\hline & $\begin{array}{l}\text { utrzymanie lub obniżenie jakości do poziomu } \\
\text { akceptowalnego }\end{array}$ \\
\hline & $\begin{array}{l}\text { utrzymanie lub podniesienie ceny do poziomu } \\
\text { akceptowalnego }\end{array}$ \\
\hline \multirow{3}{*}{ Lean Manufacturing } & obniżenie ceny poprzez minimalizację kosztów \\
\hline & $\begin{array}{l}\text { utrzymanie lub obniżenie jakości do poziomu } \\
\text { akceptowalnego }\end{array}$ \\
\hline & utrzymanie lub wydłużenie czasu realizacji zamówienia \\
\hline \multirow{3}{*}{ TQM } & maksymalizacja jakości \\
\hline & $\begin{array}{l}\text { utrzymanie lub podwyższenie ceny do poziomu } \\
\text { akceptowalnego }\end{array}$ \\
\hline & utrzymanie lub wydłużenie czasu realizacji zamówienia \\
\hline
\end{tabular}

Źródło: Interpretacja własna na podstawie TROJANOWSKA J., KOLIŃSKI A. 2011

\section{Podsumowanie}

Celem rozdziału było wskazanie na różne aspekty doskonalenia organizacji, z ukierunkowaniem na doskonalenie procesu produkcyjnego w firmach produkcyjnych. Punktem wyjścia do doskonalenia jest zrozumienie czym ten proces jest, na czym on polega, jakie korzyści można osiągnąc $\mathrm{z}$ przeprowadzenia tego procesu. $\mathrm{Z}$ tego względu zdefiniowano $\mathrm{w}$ artykule, w pierwszej kolejności pojęcie doskonałości i doskonalenia. Następnie przedstawiono różne aspekty doskonalenia 
procesu z naciskiem na proces produkcyjny - czyli określono jak, co, czym można doskonalić, jakie korzyści doskonalenie procesu produkcyjnego może przynieść firmie produkcyjnej. Zwrócono uwagę, że bardzo ważnym aspektem doskonalenia jest dobrze poznanie obiektu doskonalenia (najlepiej jego opisanie i rozrysowanie). To powinno stanowić punkt wyjście do podejmowania działań doskonalących. Zwrócono uwagę na podejścia do doskonalenia wg wymagań normy ISO 9001, oraz przedstawiono i opisano podstawowe rodzaje działań doskonalących podejmowanych $w$ przedsiębiorstwach mających wdrożony system zarządzania jakością zgodny z wymaganiami normy ISO 9001

W rozdziale podkreślono, że doskonalenie jest procesem ciągłym, ustawicznym, a samo osiągnięcie „doskonałości” jako takiej jest niemożliwe (i tak powinno być odbierane), przy czym nie należy z tego powodu rezygnować $\mathrm{z}$ podejmowania prób doskonalenia, a wręcz przeciwnie to powinno być motorem napędowym, aby ten proces nieustannie kontynuować. Działania doskonalące powinny być przeprowadzane jako cykl (mniejszych czy większych) projektów doskonalacych.

Podsumowując warto podkreślić, że skuteczne i efektywne doskonalenie wymaga wprowadzania sprawnej kultury organizacyjnej i odpowiedniego zaangażowania zarówno kierownictwa jak i samych pracowników do aktywnego poszukiwania możliwości doskonalenia (w myśl filozofii Kaizen).

\section{Literatura}

1. HorbaCZEWSKI D. 2006. Filozoficzne źródta wspótczesnego pojmowania jakości. „Problemy Jakości” 2006, nr 10.

2. HUBER Z. 2006. Doskonalenie procesów produkcyjnych. Dostępne na: http://www.huber.pl/articles/art-1.pdf 
3. SKRZYPEK E. 2010. Doskonalenie jakości jako szansa na sukces organizacji. Współczesne Zarządzanie nr 3/2010. Dostępny na: http://jml2012.indexcopernicus.com/fulltxt.php?ICID=1064258.

4. STANIEWSKA E. 2015. Doskonalenie procesu produkcyjnego przedsiębiorstwa hutniczego. Logistyka 2/2015. Dostępne na: http://www.czasopismologistyka.pl/artykuly-naukowe/send/328artykuly-na-plycie-cd-1/7368-artykul

5. SzCZEPAŃSKA K. 2011. Zarządzanie jakościa. W dążeniu do doskonatości, Wydawnictwo C.H. Beck, Warszawa.

6. Św. AMBroży. De Isaac et anima, VII.

7. TATARKIEWICZ W. 1976. O doskonatości. PWN, Warszawa.

8. TROJANOWSKA J., KolińSKI A. 2011. Strategia efektywnego zarzadzania przedsiębiorstwem poprzez adaptacyjne sterowanie produkcja. Zeszyty Naukowe Politechniki Poznańskiej. Seria: Budowa Maszyn i Zarządzanie Produkcją. Nr 6/2011, Wydawnictwo Politechniki Poznańskiej, Poznań.

9. WiŚnieWSKA M., MuZOLF A. 2012. Model doskonatości-Swissmed Excellence Model. Prace i Materiały Wydziału Zarządzania Uniwersytetu Gdańskiego. Dostępny na: http://jmf.wzr.pl/pim/2012_3_1_8.pdf

10.http://mfiles.pl/pl/index.php/Dzia\%C5\%82ania_doskonal\%C4\%85ce

11.https://pl.glosbe.com/pl/pl/doskona\%C5\%82o\%C5\%9B\%C4\%87

12.http://www.hbrp.pl/news.php?id=423\&PHPSESSID=d8d49ef253d7ec f3474c6ed7c89e2362

13.http://print-partner.com.pl/print_pub/publik/2015/doskonalosc-toosiagniecie-celu.html

14.http://sjp.pwn.pl/slowniki/doskona\%C5\%82y.html

15.http://www.statsoft.pl/Rozwiazania/Zastosowaniatechnologiczne/Optymalizacja-procesow

16.http://www.log24.pl/artykuly/przedsiebiorstwo-agile,1464 